\title{
Implementation of a bundle of care in surgical patients
}

\author{
Y Hendriks, C van Schendel, J Romme, S Alibaks, L van der Laan, R Crolla, J Kluytmans \\ From International Conference on Prevention \& Infection Control (ICPIC 2011) \\ Geneva, Switzerland. 29 June - 2 July 2011
}

\section{Introduction / objectives}

Bundles (BUN) have been proposed to improve the process of care. We describe the implementation of a BUN in surgical patients (SP).

\section{Methods}

The Amphia hospital is a large teaching hospital. In the third quarter of 2009 a BUN, defined by the national patient safety initiative, was introduced consisting of 4 components. 1) preoperative hair removal, 2) perioperative antibiotic prophylaxis, 3) normothermia and 4) limit the number of door openings. BUN compliance was measured every quarter by visual observations by dedicated infection control practioners.

\section{Results}

BUN compliance was $10 \%$ during the first 4 measurements. A multidisciplinary team analysed the reasons for non-compliance and started a program to improve the adherence. Preoperative hair removal was discouraged and when needed a clipper was used. Hypothermia was prevented by preventing cooling down during the transport of the patient to the operating room and before he entered the operating room. A strong reduction in the number of door-openings was achieved by an intensive campaign that created awareness. All HCWs in the OR were involved to create a culture of safety.

BUN compliance improved gradually over the next three quarters to $60 \%$ in the first quarter of 2011 .

\section{Conclusion}

At the start of the program the adherence to the components of the BUN was very low. This is not a unique situation as BUN adherence in Dutch hospitals

Amphia Hospital Breda, Breda, Netherlands participating in the national program in 2010 was below $10 \%$. After an intensive program that required a change in the behaviour and in the culture of the operating room workers a strong increase was observed. The implementation of a BUN is an effective tool to improve the proces of care and requires a true change in the awareness and behaviour of all HCWs.

\section{Disclosure of interest}

None declared.

Published: 29 June 2011

doi:10.1186/1753-6561-5-S6-O58

Cite this article as: Hendriks et al:: Implementation of a bundle of care

in surgical patients. BMC Proceedings 2011 5(Suppl 6):O58.
Submit your next manuscript to BioMed Central and take full advantage of:

- Convenient online submission

- Thorough peer review

- No space constraints or color figure charges

- Immediate publication on acceptance

- Inclusion in PubMed, CAS, Scopus and Google Scholar

- Research which is freely available for redistribution
() Bïomed Central 